\title{
A review of mathematical functions for the analysis of growth in poultry
}

\author{
H. DARMANi KUHI ${ }^{1}$, T. PORTER ${ }^{2}$, S. LÓPEZ ${ }^{3}$, E. KEBREAB ${ }^{4}$, \\ A.B. STRATHE ${ }^{4}$, A. DUMAS ${ }^{2}$, J. DIJKSTRA ${ }^{5}$ and J. FRANCE ${ }^{2}$; \\ ${ }^{1}$ Animal Sciences Group, Faculty of Agriculture, University of Ilam, Ilam 69315/ \\ 516, Iran; ${ }^{2}$ Centre for Nutrition Modelling, Department of Animal and Poultry \\ Science, University of Guelph, Guelph ON, N1G 2 W1, Canada; ${ }^{3}$ Instituto de \\ Ganadería de Montaña (Universidad de León - CSIC), Departamento de \\ Producción Animal, Universidad de León, E-24007 León, Spain; ${ }^{4}$ Department of \\ Animal Science, University of California, Davis, CA 95616, USA; ${ }^{5}$ Animal Nutrition \\ Group, Wageningen University, PO Box 338, 6700 AH Wageningen, The \\ Netherlands \\ *Corresponding author: jfrance@uoguelph.ca
}

Poultry industries face various decisions in the production cycle that affect the profitability of an operation. Predictions of growth when the birds are ready for sale are important factors that contribute to the economy of poultry operations. Mathematical functions called 'growth functions' have been used to relate body weight $(W)$ to age or cumulative feed intake. These can also be used as response functions to predict daily energy and protein dietary requirements for maintenance and growth (France et al., 1989). When describing growth versus age in poultry, a fixed point of inflexion can be a limitation with equations such as the Gompertz and logistic. Inflexion points vary depending on age, sex, breed and type of animal, so equations such as the Richards and López are generally recommended. For describing retention rate against daily intake, which generally does not exhibit an inflexion point, the monomolecular would appear the function of choice.

Keywords: growth functions; poultry; growth; age; intake

\section{Introduction}

Poultry industries face various decisions in the production cycle that include nutrient and mineral supply to birds, cost and type of feed and a range of bird health, welfare and environmental issues that affect the profitability of an operation. Prediction of growth and identifying the times of maximum growth rate and when the birds are ready for sale are important factors that contribute to the profitability of poultry operations. Traditionally, mathematical functions called 'growth functions' have been used to relate body weight $(W)$ to age of the bird or cumulative dietary intake (McCance, 1960; Lister et al., 1966;

(C) World's Poultry Science Association 2010

World's Poultry Science Journal, Vol. 66, June 2010

Received for publication February 9, 2010

Accepted for publication March 5, 2010 
Fitzhugh, 1976). They can also be used to determine efficiency of nutrient utilization, which is the derivative of the relationship between $W$ and cumulative dietary intake, and as response functions to predict daily energy and protein dietary requirements for maintenance and growth (France et al., 1989). A useful growth function should describe data well and contain biologically and physically meaningful parameters (France et al., 1996a). Attributes quantified using growth functions include protein deposition (Strathe et al., 2010a), body weight (Porter et al., 2010), and mineral deposition (Kebreab et al., 2010). López (2008) reviewed various nonlinear functions used in animal nutrition to represent time-dependent processes and events, and examined current and potential use of these functions to describe response to nutrients.

Growth functions can be broadly classified into three categories: those that describe diminishing returns behaviour (e.g. monomolecular), sigmoidal behaviour with a fixed point of inflexion (e.g. logistic, Gompertz, Schumacher), and sigmoidal behaviour with a flexible point of inflexion (e.g. von Bertalanffy, Richards, López (also referred to as Morgan), Weibull), as described in Chapter 5 of Thornley and France (2007). The flexible functions are often generalized models that encompass simpler models for particular values of certain additional parameters. The objective of this paper is to review the applicability of growth functions for analyzing growth profiles in poultry.

\section{Functional forms}

The functional forms of the equations commonly used for $W$ (or length or height) versus age analysis are summarized in Table 1. The monomolecular equation is the simplest nonlinear equation used in most studies reviewed and contains three parameters to be estimated. The monomolecular equation describes the progress of a simple, irreversible first-order reaction and exhibits diminishing incremental behaviour. Among the growth functions with sigmoidal behaviour, the logistic equation can be derived by assuming that the quantity of growth machinery is proportional to $W$, the growth machinery works at a rate proportional to amount of nutrient (feed) and growth is irreversible. The inflexion point is fixed at exactly half of $W_{f}$, where $W_{f}$ is theoretical final weight (mature size) of the bird (Table 1). The assumptions underlying the Gompertz equation are nutrient supply is non-limiting, the quantity of growth machinery is proportional to $W$, and effectiveness of the growth machinery decays exponentially with time according to a decay constant. Inflexion in this sigmoidal growth function is fixed and occurs at $W=$ $W_{f}$ /e. The Schumacher equation also exhibits sigmoidal behaviour with a fixed point of inflexion $\left(W=W_{f} / \mathrm{e}^{2}\right)$. Like the logistic and Gompertz, the Schumacher can also be derived as a two-state variable problem in which the specific growth rate decays according to a $3 / 2$ power function rather than log-linearly as in the Gompertz (Thornley and France, 2007).

Table 1 The functional forms used to describe the relationship between body weight, $W(t)$, and age (time) or cumulative dietary intake, $t$.

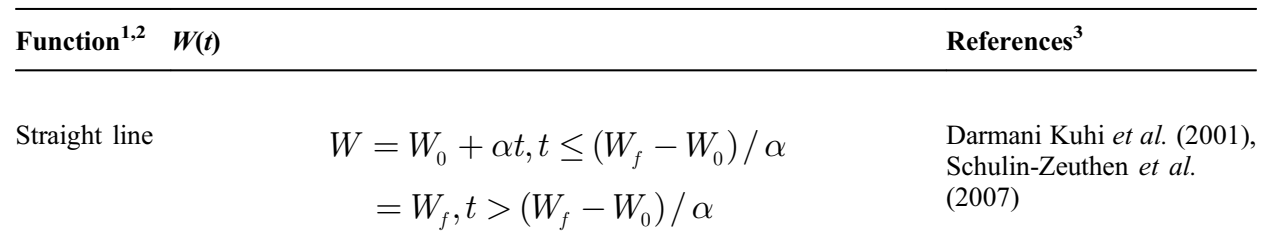


Table 1 Continued

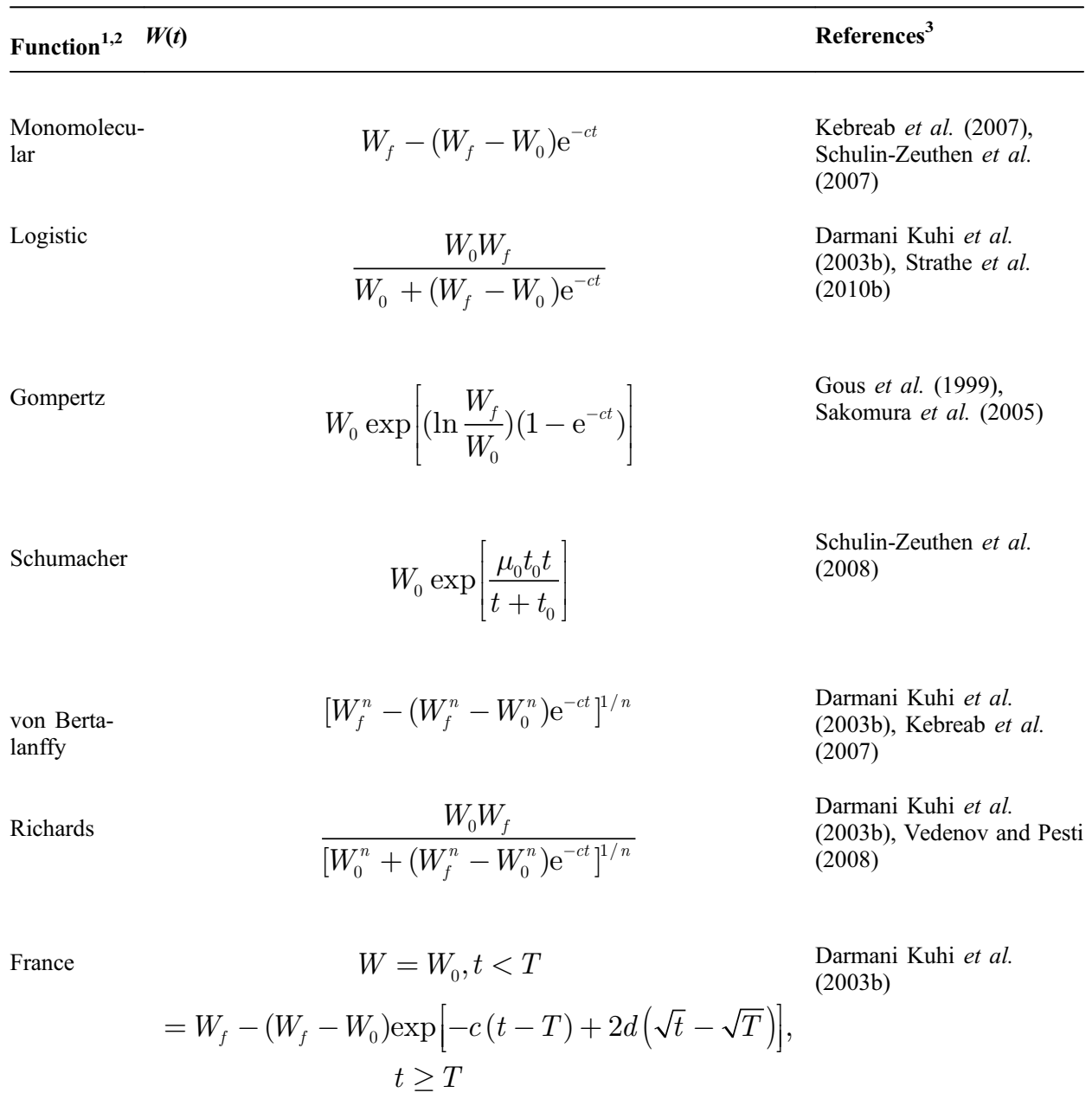

$\begin{array}{lll}\begin{array}{l}\text { López (Mor- } \\ \text { gan) }\end{array} & W=\frac{W_{0} K^{n}+W_{f} t^{n}}{K^{n}+t^{n}} & \begin{array}{l}\text { Pesti et al. (2009), Porter } \text { et } \\ \text { al. (2010) }\end{array} \\ \text { Weibull } & W_{f}-\left(W_{f}-W_{0}\right) \exp \left[-(c t)^{n}\right] & \begin{array}{l}\text { Schulin-Zeuthen } \text { et al. } \\ (2008)\end{array} \\ \text { Bridges } & W=W_{f}\left(1-\exp \left(-c t^{n}\right)\right) & \begin{array}{l}\text { Craig and Schinckel (2001), } \\ \text { Strathe } \text { et al. (2010b) }\end{array}\end{array}$

\footnotetext{
${ }^{1}$ Thornley and France (2007); ${ }^{2} W_{0}$ is initial weight, $W_{f}$ is final weight, the parameters $\mu_{0}, t_{0}, \alpha, c, d$ and $K$ are positive entities, $n \geq-1 ;{ }^{3}$ Example of recent studies with poultry or pigs where the equation has been used as a growth or response function
} 
In the von Bertalanffy equation, the assumptions are that nutrients are non-limiting, and the growth process is the difference between anabolism and catabolism. It has a flexible inflexion point that occurs at $W=(1-n)^{1 / n} W_{f}$. The Richards equation is a more empirical construct, and therefore does not have the underlying biological basis of the von Bertalanffy. However, it belongs to the same group of classic growth functions, and its flexibility, due to its shape parameter $n$ (dimensionless), makes it a generalized alternative to other equations (e.g. monomolecular, Gompertz, logistic, von Bertalanffy) (Thornley and France, 2007). The France equation is capable of describing a range of diminishing returns and sigmoidal growth patterns. It has the advantages over the Richards of being able to describe a wider variety of possibilities, and of having a more mechanistic derivation. The López equation is a generalized Michaelis-Menten equation akin to the Hill equation for enzyme kinetics. Both the France and the Lopez equations are flexible growth functions that can be derived from state variable considerations (Thornley and France, 2007).

The differential form of the Weibull equation is non-autonomous (i.e. explicitly timedependent), so the equation cannot be derived as a state variable problem and therefore has little credible mechanistic basis in terms of a simple model. Nonetheless, it is a well behaved and useful function. A special case of the Weibull (with $W_{0}=0$ ) is the Bridges equation. The initial condition $W_{0}=0$ might well limit its applicability in the study of growth curves in poultry.

\section{Historical development}

Graphical representation of animal growth was current prior to the 1920s when early fast growth rate, point of inflexion, and slow approach to final asymptotic weight were apparently based on visual appraisal of growth curves (e.g. Ritzman, 1917). However, mathematical descriptions of these curves were almost non-existent. The sigmoidal shape of the trajectory indicated that linear regression was not suitable to describe growth, unless small portions of the curve only are considered or data are transformed. Description and prediction of growth using equations emerged in agriculture from two different directions: equations were either borrowed from human population studies or developed specifically for animals and plants.

Mitscherlich-Königsberg (1909) proposed an equation with no accelerating phase to describe the effect of chemical fertilisers on crop yields. The growth response obeyed the law of diminishing increments, meaning that growth rate decreased continually and that the curve had no point of inflexion. This equation is more commonly referred to as the 'monomolecular' because of its association with chemical reaction kinetics. Wood and Yule (1914) referred to the law of diminishing increments in describing the relationship between body weight gain and swede (rutabaga) intake in oxen, but did not mention explicitly whether they used the monomolecular. Body weight as a function of feed intake was first described using the monomolecular in poultry science by Jull and Titus (1928) and Hendricks (1931) in studies with chickens. The monomolecular is inadequate to describe the sigmoidal growth trajectory of young birds and mammals with respect to time. Therefore, Brody (1945) brought the exponential and monomolecular equations together to generate a curve having a sigmoidal shape. The monomolecular (Mitscherlich) was first proposed by Blaxter and Boyne (1978) for describing the relationship between energy retention and feed intake, based on a detailed analysis of over 80 calorimetric experiments with sheep and cattle. Previously, this non-linear relationship had been approximated with two straight lines intersecting at zero energy retention (i.e. maintenance) (Blaxter and Wainman, 1961). 
The logistic equation, developed by the mathematician Verhulst (1838), was first applied to animals by Robertson (1916, 1923), and thereafter by Pearl (1925), who described the growth of mammals, plants, and yeast cells. Robertson (1908) had originally applied the logistic to plants in studying autocatalysis. The Gompertz equation (Gompertz, 1825) was first used as a growth function in animal science by Wright (Wright, 1926; Winsor, 1932), a geneticist, who stated that growth curves of individual organisms display an asymmetrical $S$-shape which is better described by a loglog equation than by the logistic. Wright (1926) never referred to Gompertz in his paper, but the equation he brought forward was in reality a linearised form of the Gompertz (Wright, 1926; Winsor, 1932). Two years later, Davidson (1928) described the growth of Jersey cows using the Gompertz. He was arguably one of the first to note that the point of inflexion of the Gompertz is fixed and corresponds to maximum asymptotic body weight divided by the base of natural logarithms. Winsor (1932) probably contributed to the popularisation of the Gompertz in biology through his paper read at the US National Academy of Sciences, and it has been used for purposes other than growth analysis, e.g. to estimate glucose oxidation in broiler chickens (Buyse et al., 2004). Schulin-Zeuthen et al. (2008) introduced another sigmoidal function, the Schumacher equation, into animal science to describe growth in pigs. The Schumacher is analysed in detail by Thornley and France (2007) and deviates considerably from its original empirical construct described in Schumacher (1939) to represent timber yield.

The rise of systemics, a collection of organised and interrelated concepts to explain causality, in science between 1920 and 1950 probably fostered the mechanistic representation of growth (Dumas et al., 2008). Growth functions that attempt to include biologically meaningful parameters and circumvent concerns about a fixed point of inflexion as assumed in the logistic and Gompertz equations arose mostly during this time period. Pütter (1920) conceptualized growth as anabolism prevailing over catabolism. The biologist von Bertalanffy, a pioneer of systemics (von Bertalanffy, 1950), borrowed the concept proposed by Pütter (1920) and formalized it (von Bertalanffy, 1957; Ricker, 1979), incorporating various assumptions such as allometry and size dependence, to derive his growth function. The equation has an asymptote, $W_{f}$, and a flexible point of inflexion (Thornley and France, 2007). Prior to von Bertalanffy, Murray (1921) considered growth as a metabolic process and applied his equation to farm animals using a value of two-thirds for the allometric exponent. Murray (1921) did not refer to Pütter, nor differentiate between anabolism and catabolism in its mathematical expression, and therefore gave no biological interpretation of the equation parameters. However, it was assumed that metabolism adheres to the surface law and, for this reason, adopted the value two-thirds. Lotka (1925), another pioneer of systemics, proposed a similar equation, but overlooked the metabolic processes in play.

Richards (1959), a botanist, starting with the von Bertalanffy equation, developed a more generic function. The Richards equation has four parameters and encompasses the von Bertalanffy, Gompertz, logistic and monomolecular equations. The inflexion point can occur at various fractions of the maximum asymptotic weight. The function is generally flexible and accommodates various growth patterns (Thornley and France, 2007). It is sometimes referred to as the four-parameter logistic (e.g. Gahl et al., 1991). The France equation is capable of describing a range of diminishing returns and sigmoidal growth patterns (France et al., 1996b). It has the advantages over the Richards of being able to describe a wider variety of possibilities, and of having a more mechanistic derivation. The López equation is a generalized Michaelis-Menten akin to the Hill equation for enzyme kinetics (Hill, 1910; Michaelis and Menten, 1913). It was derived as a growth function by López et al. (2000) and proposed earlier as a response function by Morgan et al. (1975). It is sometimes referred to as the saturation kinetics 
model when used to analyse nutritional response data (e.g. Vedenov and Pesti, 2008). The López encompasses the simple Michaelis-Menten, a diminishing returns equation which, although originally intended for enzyme kinetics, has been used to describe weight gain of animals, effect of substrate on bacterial growth rate, and biochemical flows in process-based simulation models of metabolism (Monod, 1942; Koehler et al., 1988; López et al., 2000). Both the France and the Lopez equations are flexible growth functions that can be derived from state variable considerations, unlike the Weibull equation. The latter is the cumulative density function of the Weibull distribution, a continuous probability distribution. It is named after Waloddi Weibull who described it in detail (Weibull, 1951), although it was first identified by Frechet (1927) and first applied by Rosin and Rammler (1933) to describe the size distribution of particles. The Bridges equation, a special case of the Weibull, was proposed by Bridges et al. (1992), measuring time from conception rather than from birth.

Most of these growth functions are now routinely applied in animal biology to predict growth. Furthermore these, along with chemical kinetic equations, have proven appropriate to describe complex dynamics and metabolic fluxes in mechanistic simulation models as they exhibit a wide array of dynamic behaviour.

\section{An illustrative case study}

Among nutritional factors determining rate of growth of animals, dietary energy and crude protein $(\mathrm{CP})$ are without doubt the most important ones. The usefulness of growth functions, particularly the monomolecular equation, to predict daily energy and protein dietary requirements for maintenance and growth has recently been demonstrated in broilers and turkeys (Darmani-Kuhi et al., 2003a, 2004, 2009 and Kebreab et al., 2008). This illustrative case study aims to apply the monomolecular to provide an estimate of cumulative metabolisable energy (ME) requirements, $\mathrm{CP}$ requirement for maintenance, and efficiency of CP utilisation for growth in growing turkeys.

\section{MATERIALS AND METHODS}

Data sets, shown in Table 2, and the function forms, $f(x)$, listed in Table 3 and 4, were used to investigate the relationships between body weight and cumulative ME intake, and between body weight gain and CP intake in two different analyses (Analysis I and II, respectively). Note that growth functions (Table 1) need to be re-parameterised before application to retention versus intake data (i.e. rate against rate) to permit negative values of the intercept on the $y$-axis (France et al., 1989).

Table 2 Data sources used in the case study.

\begin{tabular}{|c|c|c|c|}
\hline Source & $\begin{array}{l}\text { Growth } \\
\text { phase } \\
\text { (wk) }\end{array}$ & Strain and $\operatorname{sex}^{1}$ & Consideration \\
\hline Hurwitz et al. $(1983)^{2}$ & $0-21$ & British United (M) & $\begin{array}{l}\text { Experimental validation of model } \\
\text { calculated requirements }\end{array}$ \\
\hline Moran et al. (1984) & $0-24$ & $\begin{array}{l}\text { Nicholas (M) } \\
\text { British United (M) } \\
\text { Hybrid (M) }\end{array}$ & $\begin{array}{l}\text { Divergent feeding systems (North } \\
\text { America and Western Europe systems) }\end{array}$ \\
\hline Summers et al. (1989) & $4-20$ & Large White Nicholas (M) & Diets varying in protein content \\
\hline NRC (1994) & $0-24$ & Large Type Turkey (M) & - \\
\hline $\operatorname{NRC}(1994)^{2}$ & $0-20$ & Large Type Turkey $(\mathrm{F})$ & - \\
\hline
\end{tabular}


Growth functions in poultry: H. Darmani Kuhi et al.

\begin{tabular}{llll}
\hline Source & $\begin{array}{l}\text { Growth } \\
\text { phase } \\
\text { (wk) }\end{array}$ & Strain and sex & Consideration \\
\hline Waldroup et al. (1997) & $4-20$ & Large White Nicholas (M) & $\begin{array}{l}\text { Effects of amino acid concentrations } \\
(100,110 \text { and 120\% of NRC) on }\end{array}$ \\
Waldroup et al. (1998) & $3-18$ & $\begin{array}{l}\text { growth performance } \\
\text { Effects of amino acid concentrations } \\
\text { British United (M) }\end{array}$ & $\begin{array}{l}(100,110 \text { and } 120 \% \text { of NRC) on } \\
\text { growth performance }\end{array}$ \\
\hline
\end{tabular}

${ }^{1} \mathrm{M}=$ male, $\mathrm{F}=$ female

${ }^{2}$ These data were only used in Analysis II

Table 3 The functional forms used in Analysis I to describe the relationship between body weight, $f(x)$, and cumulative ME intake, $x$.

\begin{tabular}{|c|c|c|c|c|}
\hline Equation & $f(x)^{1}$ & $\mathrm{~d} f(x) / \mathrm{d} x^{2}$ & $\begin{array}{c}x \text { at inflexion } \\
\left(x^{*}\right)^{2}\end{array}$ & $\begin{array}{c}f(x) \text { at inflexion } \\
\left(f^{*}\right)^{2}\end{array}$ \\
\hline Monomolecular & $a-(a-b) \mathrm{e}^{-c x}$ & $c[a-f(x)]$ & None & None \\
\hline Richards & $\frac{a b}{\left[b^{n}+\left(a^{n}-b^{n}\right) \mathrm{e}^{-c x}\right]^{1 / n}}$ & $c f(x)\left[\frac{a^{n}-[f(x)]^{n}}{n a^{n}}\right]$ & $\frac{1}{c} \ln \left[\frac{a^{n}-b^{n}}{n b^{n}}\right]$ & $\frac{a}{(n+1)^{1 / n}}$ \\
\hline
\end{tabular}

${ }^{1}$ The parameters $a$ and $b$ (both $\mathrm{g}$ ) are the final and initial values corresponding to $W_{f}$ and $W_{0}$, respectively, in Table $1 ; c\left(\mathrm{MJ}^{-1}\right)$ is positive and $n$ (dimensionless) $\geq-1$

${ }^{2} \mathrm{~d} f(x) / \mathrm{d} x$ is at its maximum at the inflexion point $\left(x^{*}, f^{*}\right)$

Table 4 The monomolecular model used in Analysis II to describe the relationship between body weight gain, $f(x)$, and CP intake, $x$.

\begin{tabular}{lll}
\hline Equation $^{\mathbf{1 , 2}}$ & $\boldsymbol{f}(\boldsymbol{x})$ & $\boldsymbol{x}_{\boldsymbol{m}}$ \\
\hline Monomolecular & $a-(a+b) \mathrm{e}^{-c x}$ & $c^{-1} \ln [(a+b) / a]$
\end{tabular}

${ }^{1}$ France et al. (1989); ${ }^{2}$ The parameters $a, b$ and $c$ are positive entities, with $f_{\max }=a$ and $f_{\min }=-b$. The expressions for $x_{m}$, where the subscript $m$ denotes maintenance, were obtained as the $x$ value when $f(x)=0$

All statistical analyses were performed using the mixed non-linear procedure of SAS (SAS, 2000). Mixed model analysis was chosen for analyses because the data were gathered from various published reports and therefore there is a need to consider the report (data source) factor as a random effect (because the studies represent a random sample of a larger population of studies). Performance of the models was evaluated using the significance level of the parameters estimated, variance of error estimate and its standard error. Comparison of models was based on Bayesian Information Criteria (BIC) (Leonard and Hsu, 2001).

\section{RESULTS}

Fitting the Richards equation (Analysis I) to the pooled cumulative ME intake data set 
showed that parameter $n$ was not significantly different from -1 . Therefore, the sigmoidal trend was discarded and diminishing returns behaviour was assumed (Figure 1a). To evaluate the performance of the monomolecular, a comparison was made with data used for the calculation of cumulative ME requirements for male turkeys proposed by NRC (1994). Body weight profiles were simulated from our model using the relevant parameter estimates and compared with data from NRC (1994) (Figure 1b). There was close agreement between the values of body weight proposed by NRC (1994) and those obtained using our model. Figure $1 c$ shows the fit of the monomolecular equation to body weight gain versus $\mathrm{CP}$ intake data in Analysis II.

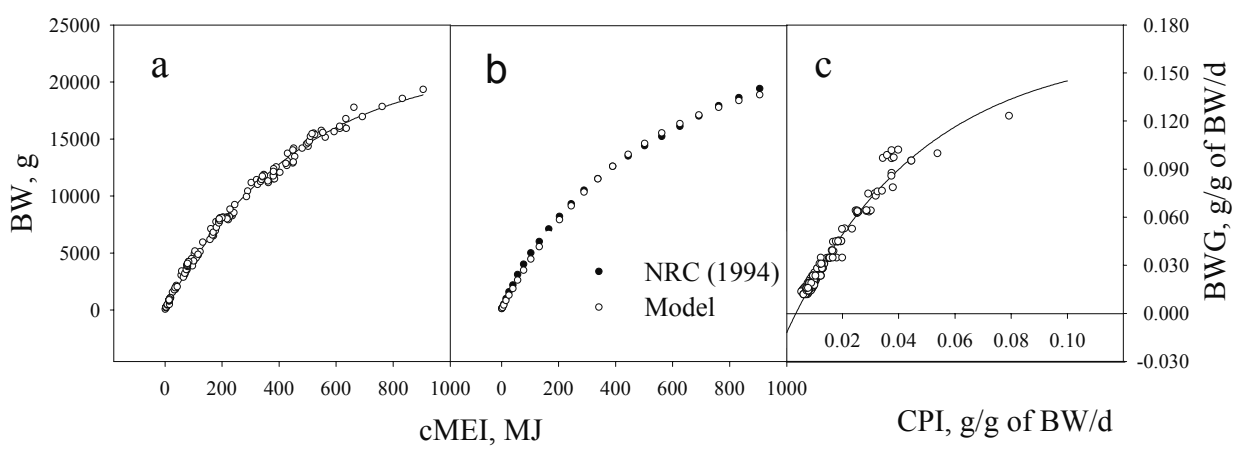

Figure 1 Plots of a) body weight (BW, g) against cumulative metabolisable energy intake (cMEI, MJ) showing the fit of the monomolecular equation (Analysis I), b) comparison between BW proposed by NRC (1994) and BW values estimated from cMEI using the monomolecular equation (Analysis I), c) rate of BW gain (BWG, g/g BW/d) against crude protein intake (CPI, g/g BW/d) showing the fit of the monomolecular equation (Analysis II).

The fitted curve and general goodness of fit, based on variation accounted for and standard error (SE) estimated for the growth parameters, indicated that fit of the monomolecular to the data sets was acceptable (Table 5).

Table 5 Parameter estimates obtained and growth indicators calculated using the monomolecular model (Analysis II), standard errors are given in parentheses ${ }^{1}$.

\begin{tabular}{|c|c|c|c|c|c|}
\hline \multicolumn{6}{|c|}{ Parameter estimates } \\
\hline$\frac{\mathrm{a}}{\mathrm{g} / \mathrm{g} \mathrm{BW} / \mathrm{d}}$ & $\begin{array}{c}\mathrm{b} \\
\mathrm{g} / \mathrm{g} \mathrm{BW} / \mathrm{d}\end{array}$ & $\begin{array}{c}\mathrm{c} \\
(\mathrm{g} \mathrm{CP} / \mathrm{g} \mathrm{BW} / \mathrm{d})^{-1}\end{array}$ & $\sigma_{\text {error }}^{2}$ & & - \\
\hline $\begin{array}{c}0.1589 \\
(0.0074)\end{array}$ & $\begin{array}{c}0.0151 \\
(0.0013)\end{array}$ & $\begin{array}{l}22.95 \\
(1.62)\end{array}$ & $\begin{array}{c}0.000014 \\
(0.000002)\end{array}$ & 96.45 & - \\
\hline \multicolumn{6}{|c|}{ Calculated growth indicators ${ }^{2}$} \\
\hline$x_{m}$ & $20 \times \bar{k}_{g}(1-4)^{3}$ & $\bar{k}_{g}$ & $\bar{k}_{g}$ & $\bar{k}_{g}$ & $\bar{k}_{g}$ \\
\hline $\mathrm{g} \mathrm{CP} / \mathrm{kg} \mathrm{BW} / \mathrm{d}$ & $\%$ & $(1-4)^{4}$ & $(1-2)^{4}$ & $(2-3)^{4}$ & $(3-4)^{4}$ \\
\hline 3.95 & 64.2 & 3.21 & 3.49 & 3.19 & 2.91 \\
\hline
\end{tabular}

${ }^{1}$ Number of observations $=199$

${ }^{2}$ Indicators calculated based on parameter estimates for $a, b$ and $c^{3}$ The average net protein utilisation for growth 
between 1-4 times maintenance calculated based on the assumption that the carcass of turkeys contains approximately $20 \%$ crude protein

${ }^{4}$ The average efficiency of $\mathrm{CP}$ utilization for growth (g gain/g CP) between 1-4, 1-2, 2-3 and 3-4 times maintenance

\section{INFERENCE}

Based on statistical performance and the biological interpretability of the parameter estimates, it was found that the data could be accurately described by the monomolecular equation (Table 5 and Figure 1). The CP requirement for maintenance $(3.95 \mathrm{~g} / \mathrm{kg}$ body weight/d) and average net protein utilisation for growth between 1-4 times maintenance $(64 \%)$, calculated based on parameter estimates for the monomolecular (Table 5), agree well with previous studies (Kebreab et al., 2008).

\section{Comparing growth functions}

Comparison of three and four parameter growth functions shows that in many cases a four parameter growth function is required to describe growth versus age adequately. Darmani Kuhi et al. (2003b) compared the Gompertz, logistic, López, Richards, von Bertalanffy and France equations for describing growth in meat and egg strains of chicken. In general the authors found the four parameter equations gave a better fit but all parameter estimates were not always significant. The Richards was found to be the best fitting model and the Gompertz fitted better than the logistic due to the lower inflexion point observed in the data. Therefore, consideration of flexible growth functions as an alternative to simpler equations (with a fixed point of inflexion) for describing the relationship between body weight and age are recommended in chickens (Darmani Kuhi et al., 2003b). However, using the Richards equation can sometimes lead to optimisation problems and the process can fail to converge, primarily due to difficulty in estimating initial $W\left(W_{0}\right)$ values. If $W_{0}$ is known and does not need to be estimated, fixing $W_{0}$ might solve the problem of non-convergence with the Richards. On the other hand, if $W_{0}$ has already been estimated using the equation, fixing it might worsen the fit (France et al., 1996a).

Porter et al. (2010) compared three flexible growth functions (von Bertalanffy, Richards, and López) and evaluated them with regard to their ability to describe the relationship between $W$ and age in growing turkey hens from commercial flocks. They also compared the flexible functions with the Gompertz. The authors reported that the fixed inflexion point of the Gompertz was a limitation, and that the relationship between $W$ and age in turkeys was best described using flexible growth functions. However, they ran into optimisation problems with the Richards and reported that the López was best in describing growth in turkeys.

Similar to poultry growth, Kebreab et al. (2007) reported for pigs that using a more complex (four parameter) function resulted in lower BIC values (therefore, better) than using three parameter functions and the additional parameter was justified because it gave flexibility to a growth function. The authors argue that although the Gompertz has been used extensively, four parameter growth functions such as the Richards were superior in describing growth over time and are recommended for use in growth data analysis in monogastric animals. Among the four parameter growth functions, Schinckel et al. (2006) showed that the López equation produced a marginally better fit for pig growth data than the Weibull and the Bridges equations. Strathe et al. (2010b) compared four growth functions to describe growth profiles from barrows, boars, and gilts and reported that based on Akaike Information Criteria (Burnham and Anderson, 
2002) the ranking was López $>$ Bridges $>$ Gompertz $>$ Logistic. One of the reasons for the Logistic equation performing poorly when describing growth is the inflexion point occurs at a much earlier stage than half mature body size. The Gompertz has a lower inflexion point compared to the logistic and usually does better in describing growth. Schulin-Zeuthen et al. (2008) reported that the Schumacher equation did better than the Gompertz based on BIC values. Part of the reason could be that, in the Schumacher, the inflexion point occurs at an earlier age compared to the Gompertz and the logistic. The authors also reported that the Weibull was better than the Gompertz based on residual mean squares but some of the parameters were not significant.

A diminishing returns rather than a sigmoidal function is in most cases all that is required to describe growth versus cumulative dietary intake or rate of retention versus daily nutrient intake adequately. A standard growth function needs to be re-parameterised before it can be applied retention versus intake data to allow negative values of the $y$-axis intercept (France et al., 1989). Our case study has demonstrated the applicability of the monomolecular to these analyses in growing turkeys, a result confirmed previously for broilers (Darmani-Kuhi et al., 2003a, 2009 and Kebreab et al., 2008) and turkeys (Darmani-Kuhi et al., 2004).

\section{Conclusions}

For describing growth versus age in poultry and pigs, a fixed point of inflexion can be a limitation with equations such as the Gompertz and logistic. In general, the point of inflexion occurs at weights less than half of final weight and varies depending on age, sex, breed and type of animal. Therefore, it has been reported in many cases that four parameter equations with a flexible inflexion point fit growth data better. In some cases optimisation problems can occur with equations such as the Richards but consideration is needed on a case by case basis. The López has frequently been shown to be an appropriate mathematical function for growth profile analysis in both poultry and pigs. For describing growth versus cumulative dietary intake and retention rate against daily intake, which generally do not exhibit an inflexion point, the monomolecular would appear the function of choice.

\section{References}

BLAXTER, K.L. and BOYNE, A.W. (1978) The estimation of nutritive value of feeds as energy sources for ruminants and the derivation of feeding systems. Journal of Agricultural Science 90: 47-68.

BLAXTER, K.L. and WAINMAN, F.W. (1961) The utilization of food by sheep and cattle. Journal of Agricultural Science 57: 419-425.

BRIDGES, T.C., TURNER, L.W., STAHLY, T.S., USRY, J.L. and LOEWER O.J. (1992) Modeling the physiological growth of swine part I: Model logic and growth concepts. Transactions of ASAE 35: 10191028.

BRODY, S. (1945) Bioenergetics and Growth with Special Reference to the Efficiency Complex in Domestic Animals. New York, USA: Hafner Publishing Company Inc.

BURNHAM, K.P. and ANDERSON, D.R. (2002) Model Selection and Multimodel Inference - A Practical Information-Theoretic Approach. New York, USA: Springer.

BUYSE, J., GEYPENS, B., MALHEIROS, R.D., MORAES, V.M., SWENNEN, Q. and DECUYPERE, E. (2004) Assessment of age-related glucose oxidation rates of broiler chickens by using stable isotopes. Life Sciences 75: 2245-2255.

CRAIG, B.A. and SCHINCKEL, A.P. (2001) Nonlinear mixed effects model for swine growth. Professional Animal Scientist 17: 256-260.

DARMANI KUHI, H., KEBREAB, E., LOPEZ, S. and FRANCE, J. (2003a) A comparative evaluation of functions for the analysis of growth in male broilers. Journal of Agricultural Science 140: 451-459. 
DARMANI KUHI, H., KEBREAB, E. LÓPEZ, S. and FRANCE, J. (2003b) An evaluation of different growth functions for describing the profile of live weight with time (age) in meat and egg strains of chicken. Poultry Science 82: 1536-1543.

DARMANI KUHI, H., KEBREAB, E., LÓPEZ, S. and FRANCE, J. (2004) A comparative evaluation of functions for describing the relationship between live-weight gain and metabolizable energy intake in turkeys. Journal of Agricultural Science 142: 691-695.

DARMANI KUHI, H., KEBREAB, E., LÓPEZ, S. and FRANCE, J. (2009) Application of the law of diminishing returns to estimate maintenance requirement for amino acids and their efficiency of utilization for accretion in young chicks. Journal of Agricultural Science 147: 383-390.

DARMANI KUHI, H., KEBREAB, E., OWEN, E. and FRANCE, J. (2001) Application of the law of diminishing return to describing the relationship between metabolizable energy intake and growth rate in broilers. Journal of Animal and Feed Sciences 10: 661-670.

DAVIDSON, F.A. (1928) Growth and senescence in purebred Jersey cows. University of Illinois Agriculture Experimental Station Bulletin 302: 182-235.

DUMAS, A., DIJKSTRA, J. and FRANCE, J. (2008) Mathematical modelling in animal nutrition: a centenary review. Journal of Agricultural Science 146: 123-142.

FITZHUGH, H.A. JR. (1976) Analysis of growth curves and strategies for altering their shape. Journal of Animal Science 42: 1036-1051.

FRANCE, J., DHANOA, M.S., CAMMELL, S.B., GILL, M., BEEVER, D.E. and THORNLEY, J.H.M. (1989) On the use of response functions in energy balance analysis. Journal of Theoretical Biology 140: 8399.

FRANCE, J., DIJKSTRA, J. and DHANOA, M.S. (1996a) Growth functions and their application in animal science. Annales de Zootechnie 45: 165-174.

FRANCE, J., DIJKSTRA, J., THORNLEY, J.H.M. and DHANOA, M.S. (1996b) A simple but flexible growth function. Growth, Development and Aging 60: 71-83.

FRÉCHET, M. (1927) Sur la loi de probabilité de l'écart maximum. Annales de la Société Polonaise de Mathematique 6: 93-116.

GAHL, M.J., FINKE, M.D., CRENSHAW, T.D. and BENEVENGA, N.J. (1991) Use of a four parameter logistic equation to evaluate the response of growing rats to ten levels of each indispensable amino acid. Journal of Nutrition 121: 1720-1729.

GOMPERTZ, B. (1825) On the nature of the function expressive of the law of human mortality, and on a new mode of determining the value of life contingencies. Philosophical Transactions of the Royal Society of London 115: 513-583

GOUS, R.M., MORAN JR., E.T., STILBORN, H.R., BRADFORD, G.D. and EMMANS, G.C. (1999) Evaluation of the parameters needed to describe the overall growth, the chemical growth, and the growth of feathers and breast muscles of broilers. Poultry Science 78: 812-821.

HENDRICKS, W.A. (1931) Fitting the curve of the diminishing increment to feed consumption-live weight growth curves. Science 74: 290-291.

HILL, A.V. (1910) The combinations of haemoglobin with oxygen and with carbon monoxide I. Journal of Physiology 40: 471-480.

HURWITZ, S., FRISCH, A., BAR, U., EISNER, I., BENGAL, I. and PINES, M. (1983) The amino acid requirements of growing turkeys. 1. Model construction and parameter estimation. Poultry Science 62: $197-$ 205.

JULL, M.A. and TITUS, H.W. (1928) Growth of chickens in relation to feed consumption. Journal of Agricultural Research 36: 541-550.

KEBREAB, E., FRANCE, J., DARMANI KUHI, H. and LOPEZ, S. (2008) A comparative evaluation of functions for partitioning nitrogen and amino acid intake between maintenance and growth in broilers. Journal of Agricultural Science 146: 163-167.

KEBREAB, E., SCHULIN-ZEUTHEN, M., LÓPEZ, S., DIAS, R.S., DE LANGE, C.F.M. and FRANCE, J. (2007) Comparative evaluation of mathematical functions to describe growth and efficiency of phosphorus utilization in growing pigs. Journal of Animal Science 85: 2498-2507.

KEBREAB, E., STRATHE, A.B., YITBAREK, A., NYACHOTI, C.M., DIJKSTRA, J., LÓPEZ, S. and FRANCE, J. (2010) Modelling the efficiency of phosphorus utilization in growing pigs. Journal of Animal Science, in press

KOEHLER, R., PAHLE, T., GRUHN, K., ZANDER, R., JEROCH, H. and GEBHARDT, G. (1988) Estimation of the rates of protein synthesis for the whole body of growing broilers. Archives of Animal Nutrition 38: 565-572.

LEONARD, T. and HSU, J.S.J. (2001) Bayesian Methods. Cambridge, UK: Cambridge Univ. Press.

LISTER, D., COWEN, T. and McCANCE, R.A. (1966) Severe under-nutrition in growing and adult animals. British Journal of Nutrition 20: 633-639. 
LÓPEZ, S., FRANCE, J., GERRITS, W.J.J., DHANOA, M.S., HUMPHRIES, D.J. and DIJKSTRA, J. (2000) A generalized Michaelis-Menten equation for the analysis of growth. Journal of Animal Science 78: 1816-1828.

LÓPEZ, S. (2008) Non-linear functions in animal nutrition, in: FRANCE, J. \& KEBREAB, E. (Eds.) Mathematical Modelling in Animal Nutrition, pp. 47-88 (Wallingford, UK: CAB International).

LOTKA, A.J. (1925) Elements of Physical Biology. Baltimore: Williams and Wilkins Company.

McCANCE, R.A. (1960) Severe under-nutrition in growing and adult animals. 1. Production and general effects. British Journal of Nutrition 14: 59-73.

MICHAELIS, L. and MENTEN, M.L. (1913) Die Kinetik der Invertinwirkung. Biochemische Zeitschrift 49: 333-369.

MITSCHERLICH-KÖNIGSBERG, E.I. (1909) Das Gesetz des Minimums und das Gesetz des abnehmenden Bodenertrages. Landwirtschaftliche Jahrbücher 38: 537-552.

MONOD, J. (1942) Recherches sur la Croissance des Cultures Bactériennes, 2me Édn. Paris: Hermann.

MORAN, E.T., POSTE, L.M., FERKET, P.R. and AGAR, V. (1984) Response of large tom turkeys differing in growth characteristics to divergent feeding systems: performance, carcass quality, and sensory evaluation. Poultry Science 63: 1778-1792.

MORGAN, P.H., MERCER, L.P. and FLODIN, N.W. (1975) General model for nutritional responses of higher organisms. Proceedings of the US National Academy of Science 72: 4327-4331.

MURRAY, J.A. (1921) Normal growth in animals. Journal of Agricultural Science 11: 258-274.

NATIONAL RESEARCH COUNCIL (1994) Nutrient Requirements of Poultry, ninth revised edition. Washington DC, USA: National Academy Press.

PEARL, R. (1925) The Biology of Population Growth. New York, USA: Alfred A. Knopf Inc.

PESTI, G.M., VEDENOV, D., CASON, J.A. and ILLARD, L. (2009) A comparison of methods to estimate nutritional requirements from experimental data. British Poultry Science 50: 16-32.

PORTER, T., KEBREAB, E. DARMANI KUHI, H., LÓPEZ, S., STRATHE, A.B. and FRANCE, J. (2010) Flexible alternatives to the Gompertz equation for describing growth with age in turkey hens. Poultry Science 89: 371-378.

PÜTTER, A. (1920) Studien über Physiologische Ähnlichkeit. VI. Wachstumsähnlichkeiten. Pflügers Archiv fur die Gesamte Physiologie des Menschen und der Tiere 180: 298-340.

RICHARDS, F.J. (1959) A flexible growth function for empirical use. Journal of Experimental Botany 10: 290-300.

RICKER, W.E. (1979) Growth rates and models, in: HOAR, W.S., RANDALL, D.J. \& BRETT, J.R. (eds.) Fish Physiology, Volume VIII, pp. 677-743 (New York, USA: Academic Press).

RITZMAN, E.G. (1917) Nature and rate of growth in lambs during the first year. Journal of Agricultural Research 11: 607-623.

ROBERTSON, T.B. (1908) On the normal rate of growth of an individual and its biochemical significance. Archiv fur Entwicklungsmechanik der Organismen 25: 581-614.

ROBERTSON, T.B. (1916) Experimental studies on growth II. The normal growth of the white mouse. Journal of Biological Chemistry 24: 363-383.

ROBERTSON, T.B. (1923) The Chemical Basis of Growth and Senescence. Philadelphia: J. B. Lippincott Company.

ROSIN, P. and RAMMLER, E. (1933) The laws governing the fineness of powdered coal. Journal of the Institute of Fuel 7: 29-36.

SAKOMURA, N.K., LONGO, F.A., OVIEDO-RONDON, E.O., BOA-VIAGEM, C. and FERRAUDO, A. (2005) Modelling energy utilization and growth parameter description for broiler chickens. Poultry Science 84: $1363-1369$.

SAS (2000) SAS/STAT User's Guide, Version 8 Edition. Cary, NC, USA: SAS Inst. Inc.

SCHINCKEL, A.P., PENCE, S., EINSTEIN, M.E., HINSON, R., PRECKEL, P.V., RADCLIFFE, J.S. and RICHERT B.T. (2006) Evaluation of different mixed model nonlinear functions on pigs fed lownutrient excretion diets. Professional Animal Scientist 22: 401-408.

SCHULIN-ZEUTHEN, M., KEBREAB, E., DIJKSTRA, J., LÓPEZ, S., BANNINK, A., DARMANI KUHI, H., THORNLEY, J.H.M. and FRANCE, J. (2008) A comparison of the Schumacher with other functions for describing growth in pigs. Animal Feed Science and Technology 143: 314-327.

SCHULIN-ZEUTHEN, M. KEBREAB, E., GERRITS, W.J.J., LÓPEZ, S., FAN, M.Z., DIAS, R.S. and FRANCE, J. (2007) Meta-analysis of phosphorus balance data from growing pigs. Journal of Animal Science 85: 1953-1961.

SCHUMACHER, F.X. (1939) A new growth curve and its applicability to timber yield studies. Journal of Forestry Research 37: 819-820.

STRAThe, A.B., DANFAR, A., CHWAlibog, A., SØRENSEN, H. and KEBREAB, E. (2010a) A multivariate nonlinear mixed-effect method for analyzing energy partition in growing pigs. Journal of Animal Science, in press. 
STRATHE, A. B., DANFfER, A., SØRENSEN, H. and KEBREAB, E. (2010b) A multilevel nonlinear mixed-effects approach to model growth in pigs. Journal of Animal Science 88: 638-649.

SUMMERS, J.D., JACKSON, S. and SPRATT, D. (1989) Weight gain and breast yield of large white male turkeys fed diets varying in protein content. Poultry Science 68: 1547-1552.

THORNLEY, J.H.M. and FRANCE, J. (2007) Mathematical Models in Agriculture: Quantitative Methods for the Plant, Animal and Ecological Sciences. Second Edition. Wallingford, UK: CABI Publishing, 923 pp.

VEDENOV, D. and PESTI, G.M. (2008) A comparison of methods of fitting several models to nutritional response data. Journal of Animal Science 86: 500-507.

VERHULST, P.-F. (1838) Notice sur la loi que la population suit dans sa croissance. Correspondance, Mathématiques et Physique 10: 113-121.

VON BERTALANFFY, L. (1950) An outline of general system theory. British Journal for the Philosophy of Science 1: 134-165.

VON BERTALANFFY, L. (1957) Quantitative laws in metabolism and growth. Quarterly Review of Biology 32: $217-231$.

WALDROUP, P.W., ADAMS, M.H. and WALDROUP, A.L. (1997) Evaluation of National Research Council amino acid recommendations for large white turkeys. Poultry Science 76: 711-720.

WALDROUP, P.W., ANTHONY, N.B. and WALDROUP, A.L. (1998) Effects of amino acid restriction during starter and grower periods on subsequent performance and incidence of leg disorders in two strains of male large white turkeys. Poultry Science 77: 702-713.

WEIBULL, W. (1951) A statistical distribution function of wide applicability. Journal Applied Mechanics Transactions ASME 18: 293-297.

WINSOR, C.P. (1932) The Gompertz curve as a growth curve. Proceedings of the National Academy of Sciences 18: 1-8.

WOOD, T.B. and YULE, G.U. (1914) Statistics of British feeding trials and the starch equivalent theory. Journal of Agricultural Science: 6: 233-251.

WRIGHT, S. (1926) The biology of population growth; the natural increase of mankind - reviews. Journal of the American Statistical Association 21: 493-497. 
240 World's Poultry Science Journal, Vol. 66, June 2010 